\title{
Reconstruction and restoration of monuments of white stone architecture on the example of the church of the Image of Edessa in Abramtsevo
}

\author{
E.L. Borovaya ${ }^{1}$, T.V. Zommer ${ }^{2}$, S.N. Chernyshev ${ }^{2}$, R.Ch. Bartsits ${ }^{1}$ and P.D. Chistov ${ }^{1}$ \\ ${ }^{1}$ Moscow Region State University (MGOU), Moscow, Russia \\ ${ }^{2}$ Moscow State University of Civil Engineering, Yaroslavskoe shosse, 26, Moscow, 129337, Russia
}

\begin{abstract}
The article deals with the topic of preserving the historical appearance of objects during the reconstruction and restoration of architectural masterpieces. The analysis of the historical experience of recreating samples of ancient Russian architecture with elements of sculptural white stone reliefs is carried out on the example of the group method of work of members of the Abramtsevo art circle, imitating the activities of the national art collective. Based on the analysis of historical experience in the framework of the Abramtsevo Art Circle and their own research, the authors have established the basic principles of reconstruction and restoration of architectural monuments. When conveying of white stone works as masterpieces of ancient Russian architecture, technological techniques must be based on the ideological basis of creating an emotional and artistic atmosphere of collective creativity of folk masters. During the reconstruction and restoration of white stone architecture, it is also necessary to reproduce the natural irregularities of the walls themselves as a stylistic and functional feature of the historical time, designed to give originality to ancient buildings, taking into account the specifics of the perception of the relief of the walls of the monument as a similarity to the terrain.
\end{abstract}

\section{Introduction}

The theme of preserving the historical appearance of reconstructed objects during the restoration of architectural masterpieces becomes especially relevant in connection with modern technologies designed to combine reliability and durability with the environmental and aesthetic qualities of natural materials used in the initial construction or decoration of historical objects.

\footnotetext{
* Corresponding author: ZommerTV@mgsu.ru
} 
Restoration of architectural monuments should take place with the complex use of artistic and expressive means of architecture, sculpture, painting, design. When restoring architectural monuments, it is necessary to take into account the principle of harmonization of modern urban space, which includes both artificially formed human habitat and natural components as elements of landscape architecture.

The secrets of the technology are considered by the authors on the example of studying the experience of the Abramtsevo Art Circle on recreating white stone architecture with elements of white stone carving in the construction and decoration of the Church of the Image of Edessa in the Abramtsevo estate. [1-5].

The experience of the Abramtsevo Art Circle [6-16], which imitates the activities of a historically established folk art collective for the reconstruction, restoration and reconstruction of white stone architecture [17-20], deserves close scientific attention and creative rethinking.

\section{Materials and methods}

The material for the study was the literary sources, the data of our own research on the historical heritage of the Abramtsevo Art Circle and the experience of restoration by scientists and students of MGSU of the architectural monument of the church of the Image of Edessa in Abramtsevo.

The research methods are standard and correspond to the set goals and objectives. The methodology of theoretical and practical research is based on the theory and methods of standard comparative analysis.

\section{Results}

White stone architecture is one of the brightest pages of our history of the pre-mongol period from the middle of the XII to the end of the XVII centuries. Therefore, white stone carving as an inextinguishable art form touches the very origins of Russian culture.

White stone has been highly valued by builders and architects since ancient times. Ancient Russian churches, public buildings and residential buildings were built in Russia in large numbers due to the unique properties of white stone-limestone: homogeneous and porous structure, ease of processing, sufficient strength and high frost resistance.

Many Russian churches built of limestone are considered masterpieces of world architecture. White stone decorative carvings were used in Chernihiv, Galich, and Old Ryazan. Scattered fragments of Galician-Volyn and Old Russian white stone historical decoration have been preserved. The highest flourishing of white stone carving reached in the architecture of Vladimir and Suzdal.

It is the Vladimir-Suzdal architectural school that is notable for the appearance of a unique Old Russian style-the art of white stone carving with original decorative techniques and subjects that are radically different from the Byzantine brick patterns with majolica tiles included in the brickwork. Therefore, when considering the scientific aspects of the topic, special attention is paid to the history of the emergence of such an original direction as sculptural reliefs in the style of white stone carving of the Vladimir-Suzdal architectural school [17-19].

Varieties of limestone as an environmentally friendly natural building material are now again in demand in construction. The unique qualities of limestone allow you to create strong structures made of environmentally friendly material. They also allow you to decorate the interiors and exteriors with sculptural reliefs in the style of white stone carving, characteristic of the masterpieces of Russian architecture.

One of the advantages of limestone as a sedimentary carbonate rock is its almost ubiquitous distribution and occurrence in the form of extended layers up to several hundred kilometers long. This allows you to mechanize the extraction of limestone and minimize 
costs. The white stone interior is characterized by high thermal insulation and sound insulation properties.

When choosing limestone according to the genetic principle, the structure, texture, composition and physical and mechanical properties are taken into account: chemogenic limestone, consisting of calcite - fine-grained, dense and strong; travertine - formed by crystals of aragonite and calcite; shell limestone - macroporous, cavernous limestone, consisting of the remains of shells of various marine organisms. A common feature of these rocks are good building qualities, water solubility and fracturing.

The preservation of the historical appearance during the restoration of architectural masterpieces and the stylization of antiquity in the original design become especially relevant in connection with modern technologies designed to combine reliability and durability with aesthetic and environmental qualities.

As an object of research, we chose the experience of the Abramtsevo Art Circle [6] on the reconstruction of white stone architecture with elements of white stone carving in the form of decorative decoration of the Church of the Image of Edessa (figure 1) [1-5].

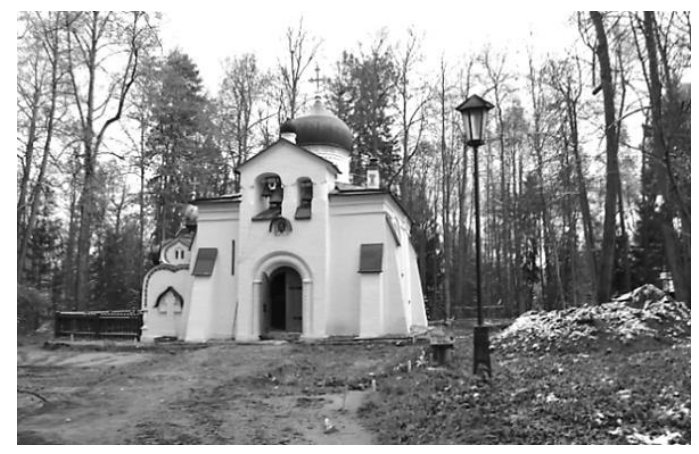

Fig. 1. Photo Borovaya E.L., Zommer T.V. Church of the Image of Edessa in Abramtsevo [1]

A small, lightweight, almost toy Church of the Saviour Not Made by Hands in Abramtsevo is located in a lighted clearing near the dacha of the artist Polenov V. D. When recreating the style of white stone architecture, members of the Abramtsevo Art circle took into account and artistically interpreted the architectural, aesthetic and environmental features of the Vladimir-Suzdal school and other architectural regional schools of Ancient Russia [6].

The work carried out by the Abramtsevo Circle on the study of Old Russian white stone architecture is particularly valuable today, as some of the unique prototype churches were almost completely destroyed during the Second World War (figure 2).
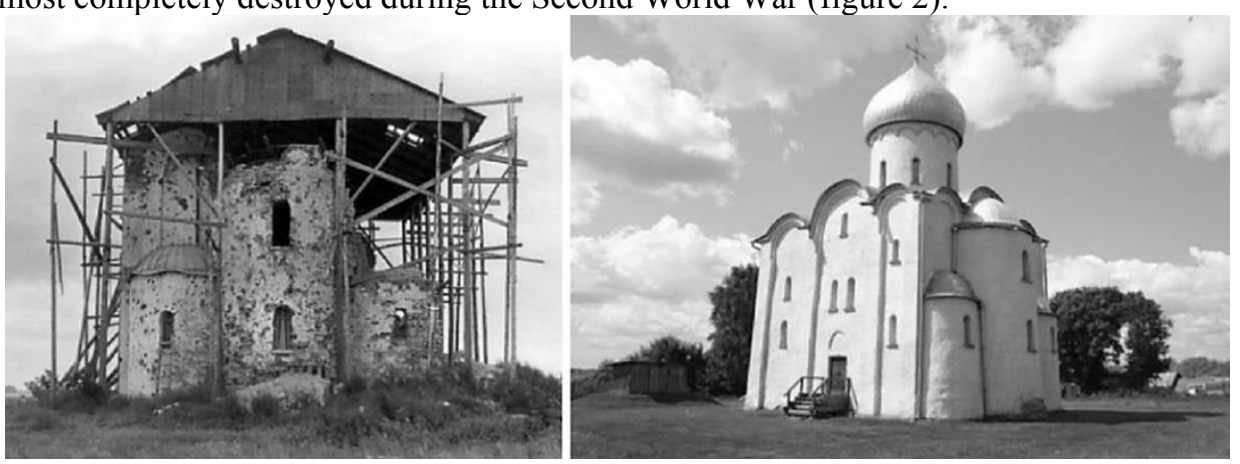

Fig. 2. Pre-mongol cultural heritage monument Church of the Savior on Nereditsa (1198): ruins of a church with a protective tent in 1947; after restoration in 1958 [7] 
The architectural idea, which initially consisted in a creative reinterpretation of the phenomenon of the white-stone Church of the Savior on Nereditsa near Novgorod the Great [19], unexpectedly led to the appearance of an original work - the Church of the Image of Edessa in Abramtsevo, which became the first monument of the Russian Art Nouveau era $[1,21,22]$.

Russian art group Abramtsevsky Circle, consisting of professional and non-professional artists, sculptors, architects, specially traveled to historical sites in Yaroslavl, Rostov, Moscow, Sergiev Posad, Novgorod and other native Russian cities and villages, where sketches were made and architectural and artistic ideas were born.

The members of the Abramtsevo Art Circle were tasked with studying the preserved examples of Russian architecture using national techniques and styles. Therefore, the Church of the Image of Edessa - is a collective work that synthesizes the experience and achievements of the national architectural schools of ancient Russia. The shape of the temple in the form of a truncated pyramid is similar to the Trinity Cathedral in the Lavra of Sergiev Posad, the appearance with the natural white stone relief of the walls is similar to the Church of the Savior on Nereditsa, the white stone sculptural reliefs remind us of the Vladimir and Moscow masterpieces of Russian architecture.

As a result, after many discussions, the Church of the Saviour Not Made with Hands in Abramtsevo was built in 1881-1882 on the estate of Savva Mamontov according to the collective project of his friends-artists V. D. Polenov and V. M. Vasnetsov, who first tried themselves as architects (figure 3) [6].
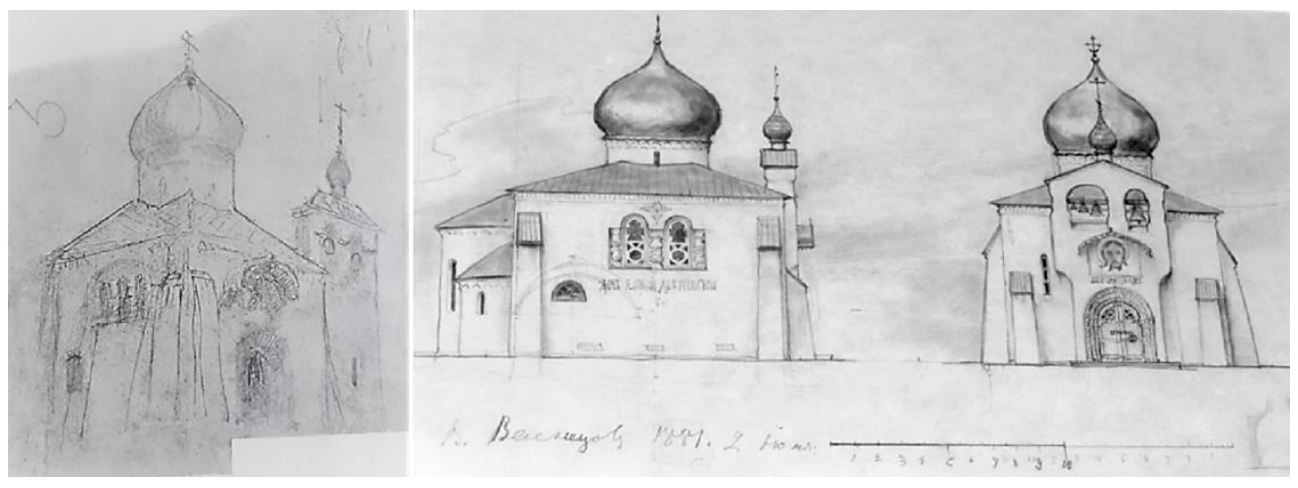

Fig. 3. Polenov V.D. Project of the church [6]; Vasnetsov V.M. The northern and western facades of the Church of the Image of Edessa (reshoot in Abramtsev: Borovaya E.L., Zommer T.V.)

Inspired by the idea of recreating ancient Russian architecture, the artist Vasily Polenov created an initial project based on the architecture of the Church of the Savior on Nereditsa of the XII century. However, after discussions, the members of the circle came to the conclusion that the project of the temple turned out to be too heavy, really copying the Old Russian architecture. Savva Mamontov wanted to move away from exact copying and introduce an element of eclecticism.

Therefore, the original project of Polenov was continued by the artist Viktor Vasnetsov, who was fond of the architecture of Moscow, Yaroslavl and Rostov churches and brought a playful and fairy-tale beginning to the construction. When working on the drawings of the church, he changed the proportions of the building and swapped the northern and southern facades, which is why the ponderous old Russian Church of the Savior on Nereditsa turned into an elegant "toy" church.

At the finishing stage, the temple was decorated with real architectural white stone reliefs. According to the memoirs of the members of the Abramtsevo circle, not only professional 
sculptors and artists, but also Savva Mamontov himself, all women and even children carved ornaments on the stone, like real stonemasons [6].

In the white stone carvings of the Church of the Saviour Not Made with Hands, there are reliefs of the tetramorph, correlated with the symbols of the evangelists: an angel (Matthew), a lion (Mark), an eagle (John) and a calf (Luke). Also in the white stone decoration of the portal of the church, sculptural reliefs with Christian symbols stand out: the lamb and the fish represent Christ, the head of the donkey reminds of the solemn entrance to Jerusalem, the rooster symbolizes the abdication of Peter, and others (figure 4).

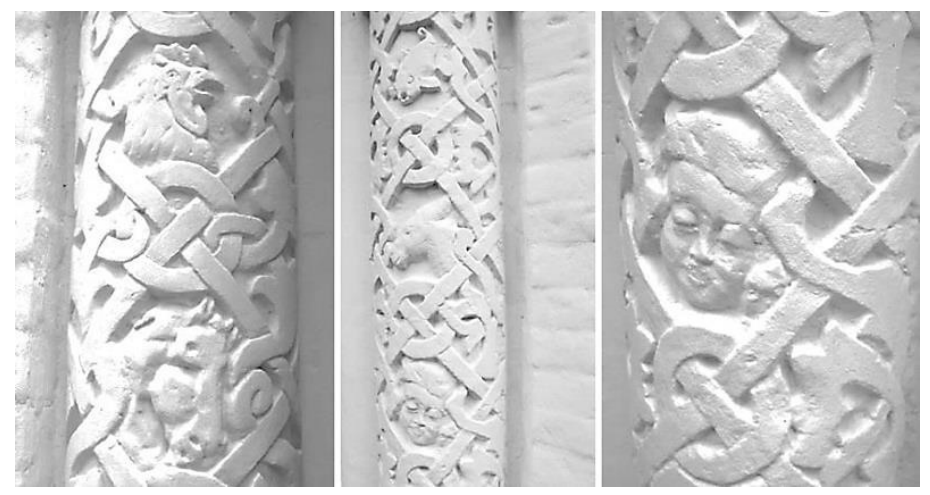

Fig. 4. Photo Borovaya E.L., Zommer T.V. Architectural details of the Church of the Image of Edessa in Abramtsevo [1]

The current of the Church of the of the Image of Edessa in Abramtsevo with white stone carvings never tires of surprising tourists and parishioners with a genuine folk spirit, a variety of sometimes unexpected sculptural subjects that could come to the mind of a famous sculptor, painter or even a child, since in collective creativity it is rarely possible to establish the authorship of a particular fragment.

The restoration of the Church of the Image of Edessa in Abramtsevo was started according to the approved project in 2006 and was carried out with the participation of students, teachers and scientists of MGSU, providing scientific support for research, design and construction.

On the site of the Church of the Image of Edessa in Abramtsevo, under the guidance of MGSU scientists, archival materials on the history of the monument were studied, geoecological engineering surveys were carried out, and a reconstruction project was prepared with the introduction of new elements $[1,2]$.

During the survey, it turned out that the elements of the white stone decoration of the church portal and window openings, made according to their own sketches in imitation of the Vladimir-Suzdal school, were preserved almost intact, although in 1930-1940 the church was used as a warehouse.

Therefore, the masterpieces of white stone carving created by the members of the Abramtsevo art circle were only slightly cleaned and remained unchanged (figure 5). 


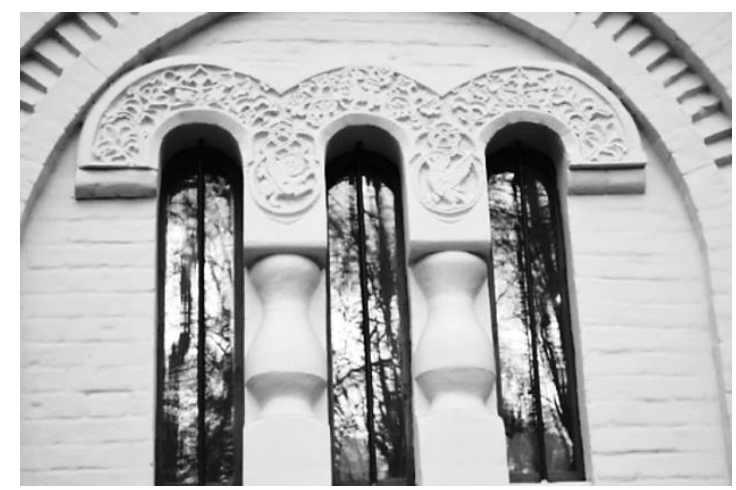

Fig. 5. Photo Borovaya E.L., Zommer T.V. Window of the southern facade of the Church of the Image of Edessa in Abramtsevo

However, during engineering surveys with the study of archival materials, it was revealed that many mistakes were initially made during the construction of the temple. The construction was started at the risk of Savva Mamontov, without the appropriate permission and engineering support. The project was officially approved only when the extensions of the church were already being built. $[2,6]$.

Of the main errors identified by the scientific group under the leadership of Professor Chernyshev S. N., it is possible to list the following. During the construction of the church, there was initially no waterproofing of the foundation from the clay filling of the trench. Clay soil in contact with the foundation masonry soaked the brick, resulting in capillary suction, and capillary moisture rose along the walls.

The foundations of the buttresses were located at a depth of freezing- $0.7 \ldots 0.8 \mathrm{~m}$, which is two times less than under the temple itself. Therefore, due to the frost heaving, the foundations and buttresses were severely deformed.

The wall of the chapel (in the annex of the temple on the left north side) was built too thin, as a result of which it froze in the cold, and condensation formed on the surface of the wall (frost appeared in winter), which led to the destruction of plaster and brickwork.

But, oddly enough, such a rapid dilapidation of the church, just built by the members of the Abramtsevo circle, did not bother anyone, as if this rapid "aging" was originally conceived by self-taught architects. Especially such a picturesque "old" was admired by artists who were happy to depict red brickwork on their canvases, which appeared in places through whitewash and other construction defects, giving the new building the effect of "patination".

After conducting engineering surveys, a project was drawn up to restore the foundations, facades and roof of the temple. Restoration work was also decided to be carried out by the Moscow University of Civil Engineering, the license for carrying out these types of work at that time was (figure 6) [2]. 


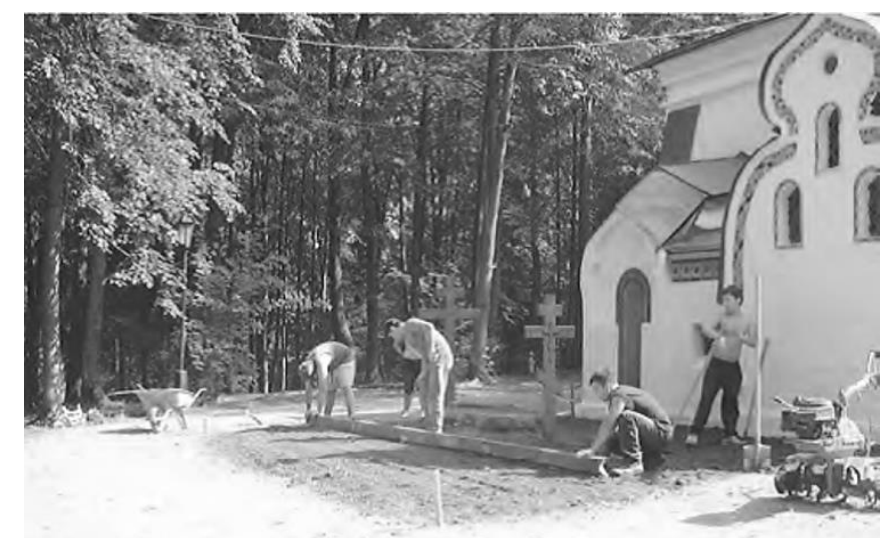

Fig. 6. Photo from the archive of Professor S.N. Chernyshev: students and teachers of MGSU and other universities at the restoration of the Church of the Image of Edessa in Abramtsevo [2].

During the restoration work, all these shortcomings were eliminated. The students repaired the foundations and the bottom of the walls, brought the foundations under the buttresses, repaired the roof, and painted the walls.

Including the lower part of the brick buttresses was dismantled and re-laid by the students. At the same time, after receiving the task, the students "overdid it": they mistakenly laid out the surfaces of the buttresses too evenly, almost like perfect planes.

This did not correspond to the idea of V.M. Vasnetsov, who wanted to make the surfaces of the walls and buttresses of the Church of the Image of Edessa as uneven as they were preserved in the Church of the Savior on Nereditsa.

Therefore, according to the agreement of the head of the survey and restoration works with the director of the museum, the masonry of the buttresses was disassembled and relaid taking into account the natural heterogeneity. As a result, some of the old masonry bricks were slightly sunk, others protrude above the surface of the wall. This enlivens the flatness of the walls and buttresses, imitating the style of Pskov and Novgorod white stone architecture.

In 2015-2017, a research group of aspirant's under the leadership of Professor Chernyshev S.N. conducted separate studies of the facade of the Abramtsevo Church of the Image of Edessa in Abramtsevo in order to identify patterns of distribution of inhomogeneities of the surface of the walls of architectural monuments (figure 7) [3-5].
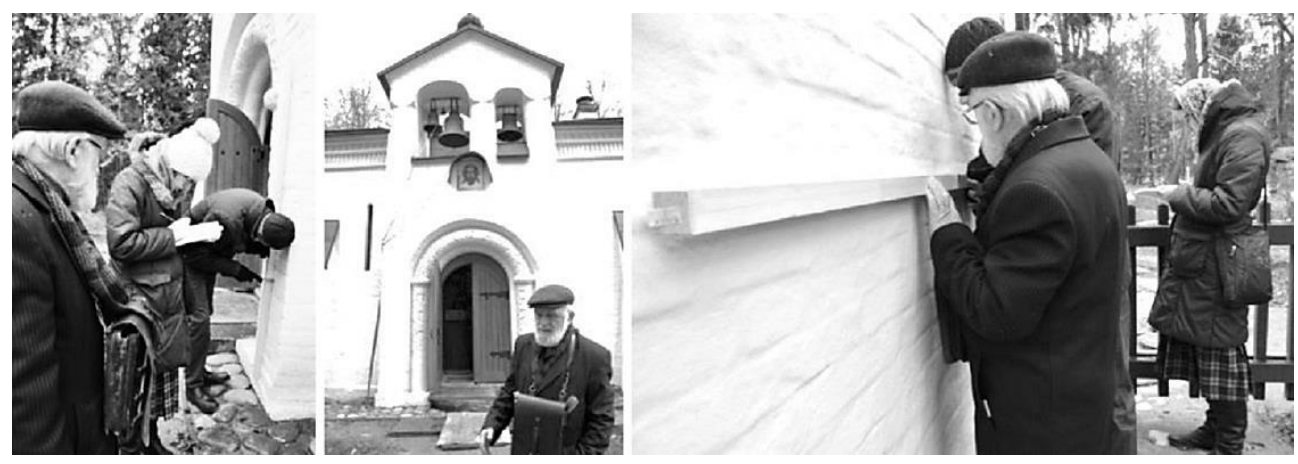

Fig. 7. Photo Borovaya E.L., Zommer T.V. A scientific group of aspirant's Chernyshev S.N. examines the natural heterogeneity of the "white stone masonry" of the Church of the Image of Edessa in Abramtsevo 
In the course of the research, a scanerogram of the western facade of the Church of the Image of Edessa in Abramtsevo was made (figure 8).

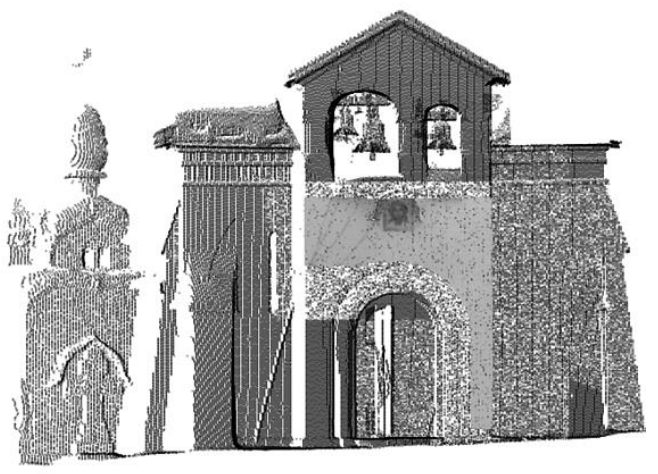

Fig. 8. Scanogram of the western facade of the Church of the Image of Edessa in Abramtsevo [3]

The architectural measurement with the relief survey was carried out, among other things, with the Trimble S6 electronic tachometer (with a measurement accuracy of $\pm 1 \mathrm{~mm}$, with a step of scanning points-up to $1 \mathrm{~cm}$ ), the scanogram was processed using the 3D Reshaper Survey Bundle program for geodetic data (figure 9).

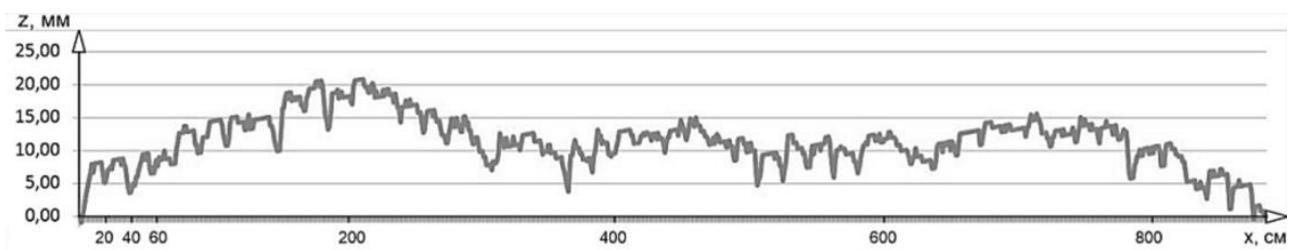

Fig. 9. Graph of deviations from the plane of the wall of the Church of the Image of Edessa in Abramtsevo [4-5]

As a result of the study, it was suggested that the irregularities of the wall created by V.M. Vasnetsov according to the type of the Church of the Savior on Nereditsa at the named ratio of the lengths of vertical and horizontal waves serve the perception of the temple as higher (figure 10).
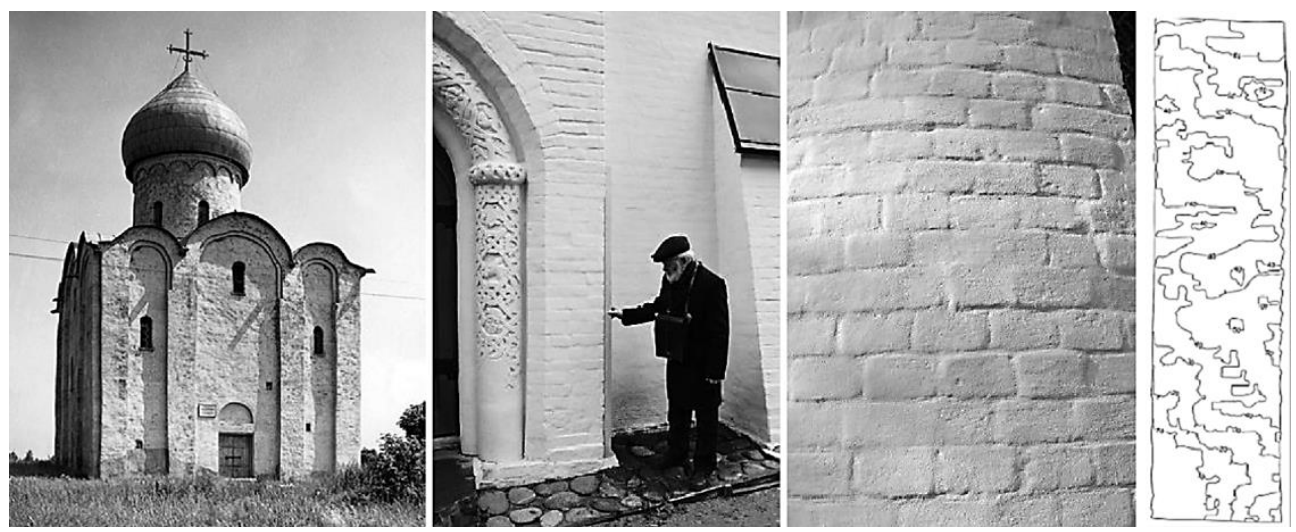

Fig. 10. Relief of the facade of the Church of the Saviour on Nereditsa after the restoration of 1958; photo Borovaya E.L., Zommer T.V.: relief of the portal of the Church of the Image of Edessa in Abramtsevo; map of the buttress surface relief [4] 
Thus, we can say that the reproduction of wall irregularities is one of the typical tasks in the reconstruction and restoration of monuments of ancient Russian architecture.Also, the implementation of irregularities can be used in modern construction in order to break the monotony of perception of extended wall panels.

\section{Conclusions}

As a result of the mistakes listed above, the Church of the Image of Edessa in Abramtsevo needs permanent repairs. The whitewashed facades of the church still require renovation, as the whitewash is peeling off in places, and the same red "brick" picturesque spots appear on the white wall.

However, this certain "dilapidation" does not prevent, but helps the perception of the Church of the Image of Edessa in Abramtsevo in Abramtsevo as an architectural monument made in the style of white stone architecture, which is combined with the original idea of self-taught architects - famous artists V.D. Polenov and V.M. Vasnetsov, members of the Abramtsevo Art circle.

The study of the issues of reconstruction of white stone architecture on the example of the Church of the Image of Edessa in Abramtsevo in Abramtsevo showed that the technological basis is based not on the exact observance of technological norms and rules, but primarily on the reconstruction of the emotional and artistic atmosphere of the community work of the art collective.

In our opinion, in general, the secret of the restoration of white stone architecture in the reconstruction and restoration of masterpieces of ancient Russian architecture is not so much in the exact observance of technology, as in the observance of the reproduction and recreation of aesthetic features inherent in the very spirit of historical time.

Recreating architectural masterpieces on the example of sculptural reliefs of white stone carvings simultaneously requires knowledge, skills and abilities in the history of art and personal practical experience in the restoration of monuments of Russian culture. The use of the group method of creating original reliefs in the style of white stone carving goes back to the idea of recreating the creative atmosphere in an experimental group that imitates the collective of the "people's" artel. It is the ideological recreation of the atmosphere of collective work of the people's art artel that ultimately determines the creative advantage in the restoration or reconstruction of architectural monuments.

The white stone carvings of the Abramtsevo Church were made in a truly folk atmosphere of a man-made miracle: by professional and non-professional artists and sculptors, poets, artists, their wives and children. Therefore, in fact, this is a real work of collective creativity of the entire Abramtsevo Mamontov art circle.

It is for this reason that the game strategy of building an Old Russian temple by a group of friends of Savva Mamontov led not to copying an old Russian masterpiece, but to creating a completely new work of art - with the revival of the style and spirit of artistic creativity in the field of white stone architecture.

\section{References}

1. Zommer T.V., Borovaya E.L., Zommer V.L., Chernyshev S.N. Ecological and aesthetic features of restoration and reconstruction of white stone architecture on the example of the Church of the Image of Edessa in Abramtsevo. Science review, 14, 58-62 (2017)

2. Chernyshev S.N. Experience of restoration and reconstruction of architectural monuments: from engineering researches to projects implementation by scientists and students of MGSU. Vestnik MGSU, 7, 18-27 (2014)

3. Chernyshev S.N., Rubtsov I.V., Elmanova E.L. Experience in using geodetic measurements to study the facade of an architectural monument, Prospects for the 
development of engineering surveys in construction in the Russian Federation, 470-474 (2017)

4. Chernyshev S.N., Elmanova E.L., Rubtsov I.V. The study of the wall relief of the architectural monument as the similarity to the terrain, Industrial and civil engineering, 4, 44-49 (2018)

5. Chernyshev S., Rubtsov I., Elmanova E. Innovative technologies in brick masonry restoration of architectural monuments. Matec Web of Conferences, 04007 (2018)

6. Polenova N.V. Abramtsevo. Vospominaniya [Abramtsevo. Memory lane]. Moscow. M. i S. Sabashnikovykh PubL, 1922. 105 p. (In Russian).

7. Hilton A. From Abramtsevo to Zakopane: folk art and national ideals in Russia and eastern Europe, Russian History, 46, 4, 241-261 (2020)

8. Hilton A. The Abramtsevo artistic circle and the search for a national landscape, Experiment, 25, 1, 68-82 (2019)

9. Paston E. Abramtsevsky circle in the concept of the exposition "Russian style. From historicism to modernism" in the all-Russian museum of decorative and applied art, 4(31), 384-399 (2019)

10. Paston E. The "dilettantism" of Savva Mamontov in Russian art, Experiment, 25, 1, 3352 (2019)

11. Kirilova A.V. The essential characteristics of art associations in russian culture, Ideas and ideals, 3(25), 92-98 (2015)

12. Chizik K.G. Abramtcevo - cradle of modern russian, Crimean dialogues: Culture, Art, Education, 2 (10), 15-18 (2016)

13. Kashtanova E. Vasilii Polenovs architectural projects: between the neo-russian style and national romanticism, Experiment, 25, 1, 158-174 (2019)

14. Skorobogacheva E.A. Temple of the Holy Face in Abramtsevo. On the problem of interpreting traditions of Northwestern Russia and the Russian North, Historical, Philosophical, Political and Law Sciences, Culturology and Study of Art. Issues of Theory and Practice, 1-2 (51), 171-177 (2015)

15. Kulinicheva E.A. G. Stickley's magazine "Craftsman": American art criticism on the Abramtsevo and Talashkino art groups, Actual Problems of Theory and History of Art, 3, 280-286 (2013)

16. Wierda I. The soil of Radonezh and the artists of Abramtsevo, Experiment, 25(1), 83100 (2019)

17. Filimonova K.E. White stone carving of the Vladimir-Suzdal land on the example of the relief decoration of the Dmitrievsky cathedral, Youth scientific bulletin, 11, 96-102 (2016)

18. Gladkaya M.G. Reliefs of the Dmitrievsky cathedral in Vladimir: the experience of a comprehensive study. M., 2006. URL: http://www.dissercat.com/content/relefydmitrievskogo-sobora-vo-vladimire-opyt-kompleksnogo-issledovaniya

19. https://commons.wikimedia.org/wiki/Category:Transfiguration_Church_in_SpasNereditsy

20. Mamontov K.V. Formation of artistic and creative needs of students in sculpture classes. M., 2006. URL: http://www.dissercat.com/content/formirovaniekhudozhestvenno-tvorcheskikh-potrebnostei-studentov-na-zanyatiyakh-skulpturoi

21. Davydova O. "Dreaming of Russia": National-romantic features in Art nouveau, Experiment, 25, 1, 189-206 (2019)

22. Antonova E.A. New national style, Ivzestia of the Volgograd State Pedagogical University, 3(67), 81-85 (2012) 